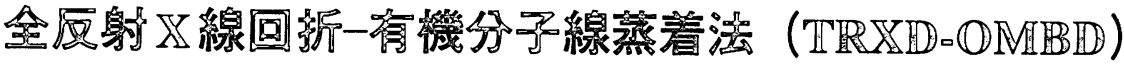 によるフラーレン超溥膜のその晹観察
}

\author{
吉田＼cjkstart郵司・谷垣 宣孝・八瀬 清志 \\ 物質工学工業技術研究所 高分子物理部 305 茨城県つくば市東 1-1 \\ （1996年5月 17 日受理）
}

\section{In-situ Observation of Fullerene Ultrathin Films by Using Total Reflection X-ray Diffraction-Organic Molecular Beam Deposition Method (TRXD-OMBD)}

Yuji Yoshida, Nobutaka TANIGAKI and Kiyoshi YASE

National Institute of Materials and Chemical Research 1-1 Higashi, Tsukuba, Ibaraki 305

(Received May 17, 1996)

\begin{abstract}
For the purpose of confirming the growth mechanism of organic ultrathin films prepared by organic molecular beam deposition (OMBD), we employed a new combined system of total reflection X-ray diffraction method (TRXD) and OMBD. By using this system (TRXD-OMBD), the in-situ observation of cohesive structures and growth modes in organic ultrathin films were performed. In this study, the in-plane structure and orientation of fullerene (C60) ultrathin films epitaxially grown on oriented silver $(\mathrm{Ag})$ surfaces were examined during the deposition. It was confirmed that the C60 ultrathin film formed the hexagonal closed packed (hcp) structure and the epitaxial structure of $\mathrm{C} 60$ on the $\mathrm{Ag} \mathrm{(111)} \mathrm{surface} \mathrm{occurred} \mathrm{at}$ the thickness of a few nanometer, namely the $(2 \sqrt{3} \times 2 \sqrt{3}) \mathrm{R} 30^{\circ}$ structure as a stable state. Further, the growth modes of C60 ultrathin films were examined by the in-situ observation of total reflection fluorescence X-rays of Ag. In this paper, we noted the possibility of various analysis on organic ultrathin films and surfaces by our TRXD-ONBD system.
\end{abstract}

\section{1.はじめに}

これまでに様々な超薄膜の構造評価法が開発されてい るが, それぞれ対象とする試料, 構造スケールおよび測 定環境が特定されたものが多く, 目的に応じて相補的に かつ効果的に用いて評価を行う必要がある。最近の超薄 膜研究の進展および多様化に伴い, より高感度でより的 確な情報を得る必要が生じてきており, 従来のものとは 異なる新たな評価法の確立が求められている。

我々は, 有機超薄膜中の分子の 2 次元凝集構造, 特に 膜厚がナノメーター領域までの初期過程での凝集構造に 注目してその評価を行っている。従来このような凝集構 造の解析には, 主に電子線をプローブとした電子線回折 法（LEED， RHEED）が用いられてきたが，電子線は有 機分子と著しく強い相互作用をするために, その電子線
損傷が問題となることが多い。一方で，STM，AFM等 の走査プローブ顕微鏡は, 局所的または表面に関して詳 細な情報が得られるが，薄膜面内の広い領域に及ぶ 2 次 元凝集構造の評価には適さない。これに対してX線回折 は, 有機物に対する損傷が少なくかつ面内凝集構造の評 価には最も適しているが，従来の手法では基板側からの 強い散乱 X線がその評価を困難なものにしてきた。

しかしながら近年, 基板に対して極低角にX線を入射 する “微小角入射 X線回折法 (GIXD)” が確立されて以 来, 有機超薄膜の分野でも主に放射光施設のような強い 光源を用いて盛んに研究が行われてきた ${ }^{123)}$ 。一方で, GIXDをさらに発展させた全反射 X線回折法 ${ }^{4)}$ (TRXD) は, 極低角入射による有機薄膜と基板の界面での全反射 現象を利用したものであり, 種々の有機超薄膜研究に応 用されて来ている5, 6)。GIXDおよびTRXDは, 近年盛ん 
に行われているX線反射率測定 ${ }^{3,7)}$ と共に, 表面および 界面の新たな非破壊評価法として期待されている。

また, 超薄膜の構造形成過程を調べるためには製膜中 での観測が重要であり，様々な評価法で “その場観測” が試みられている。我々は, このTRXD と有機分子線蒸 着法（OMBD）を組み合わせた装置を試作し, 分子線蒸 着による有機超薄膜のその場観察をすることで, その凝 集構造の形成に関する研究を行っている ${ }^{8.9) 。}$

ところで, 特徴的なサッカーボール型の分子であるフ ラーレン (C60) はその発見以来 ${ }^{10)}$, 新たな炭素系物質 として機能性に関しても興味が持たれている。最近では, 合成抒よび精製法の開発により比較的安価に材料が得ら れるようになって来たため, photoresist, SiC-precursor お よび passivation surface 等の光・電子材料としても期待さ れている。材料化の基盤技術となる蒸着膜については, 種々の基板上でその成長形態が異なり, 最近では特定の 結晶基板の表面構造と C60 結晶との格子整合条件による 解釈から，そのエピタキシャル成長による高配向特性に 関して詳細に検討されている"1。特に，金（Au）および 銀（Ag）の結晶面に押いて数百ナノメーターに及ぶ大 きなモノドメインが成長していることが観測され，C60 と金属原子との特異的な相互作用の存在が示唆されてお り, デバイス応用の観点からも注目されている ${ }^{1125)}$ 。

本研究では, TRXD-OMBD 法により $\mathrm{Ag}$ 基板上に作製 した $\mathrm{C} 60$ 蒸着膜の構造を製膜中にその場観測して，その 面内構造・成長形態を評価して凝集機構を明らかにする ことを目的とした。本稿では，その最新の結果を報告す ると共に, 本手法を用いた有機超薄膜の構造評価への 様々な応用の可能性について解説する。

\section{2. 全反射 X線回折-有機分子線蒸着法（TRXD- OMBD) について}

$\mathrm{X}$ 線を極低角で入射して基板表面で全反射させた条件 で各種の X線測定を行うことにより, その高感度化が可 能となる ${ }^{16,17)}$ 。TRXD法は, 全反射条件下で薄膜からの 回折X線を測定することで，基板からの散乱 X線を低減 して回折X線のSN比を向上させるものである（Fig. 1)。 従って, 従来の薄膜 X 線回折計では困難であった膜厚が ナノメートル領域での超薄膜の構造評価が可能となる。 また，本手法はエネルギー分散型の測定系を採用してい るため, 測定角は固定であり迅速な測定が可能であるば かりか, 蛍光 $X$ 線の高感度測定（全反射蛍光 $X$ 線分析） も同時に行うことができる。この場合, 測定角 $\left(\theta_{\mathrm{B}}\right)$, 面間隔 $\left(d_{\mathrm{hk}}\right)$ とエネルギー $\left(E_{\mathrm{hk}}\right)$ の関係は次式で示さ れる。 $(h ;$ プランク定数, $c$; 光速 $)$
Continuous $\mathrm{X}$-rays

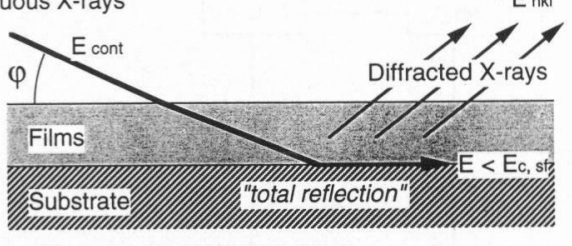

$\mathrm{E}_{\mathrm{c}, \mathrm{sf}}$; Critical energy for total reflection at Interface between films and substrates

$\varphi$; Grazing incident angle

Fig. 1 Principle of energy-dispersive type total reflection X-ray diffraction.

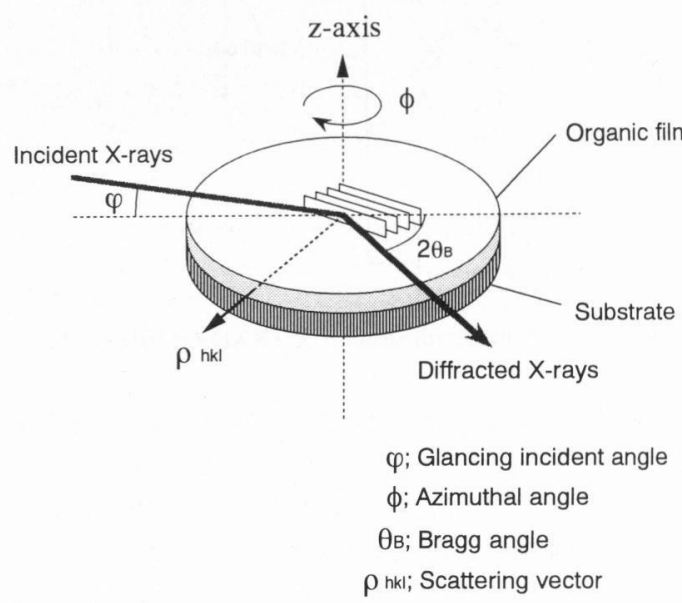

Fig. 2 The geometry of in-plane TRXD.

$$
E_{\mathrm{hkl}}=\frac{h c}{2 d_{\mathrm{hkl}} \sin \theta_{\mathrm{B}}}
$$

特に, Fig. 2 に示すような in-plane型のX線ジオメトリ 一では, 薄膜面内での分子の 2 次元凝集構造を評価する ことが可能である。また, 基板および薄膜を $\phi$ 回転させ ることで双方の面内配向および構造の方位関係を容易に 計測できるため, エピタキシャル成長した薄膜の評価に 適している。例えば, 塩化カリウム単結晶 $(\mathrm{KCl})$ 上の 長鎖有機分子 $\left(n-\mathrm{C}_{33} \mathrm{H}_{68}\right)$ のエピタキシャル蒸着膜の配向 評価に用いられた研究例があるら”。

TRXD-OMBD装置は，OMBD法により作製した蒸着膜 のその場観測を行うために，OMBD用超高真空チャンバ 一をTRXDのジオメトリー中に組み込んだ構成になって いる。Fig. 3にその装置構成を示すが，X線源には回転 対陰極型 X線発生装置（タングステン, $18 \mathrm{~kW}$, リガク） を, X線検出部にはSSD (pure-Ge型, キャンベラ) を使 用している。真空チャンバーの入射側と回折側に円形の ベリリウム空を用いることで，内部にある蒸着膜試料の 


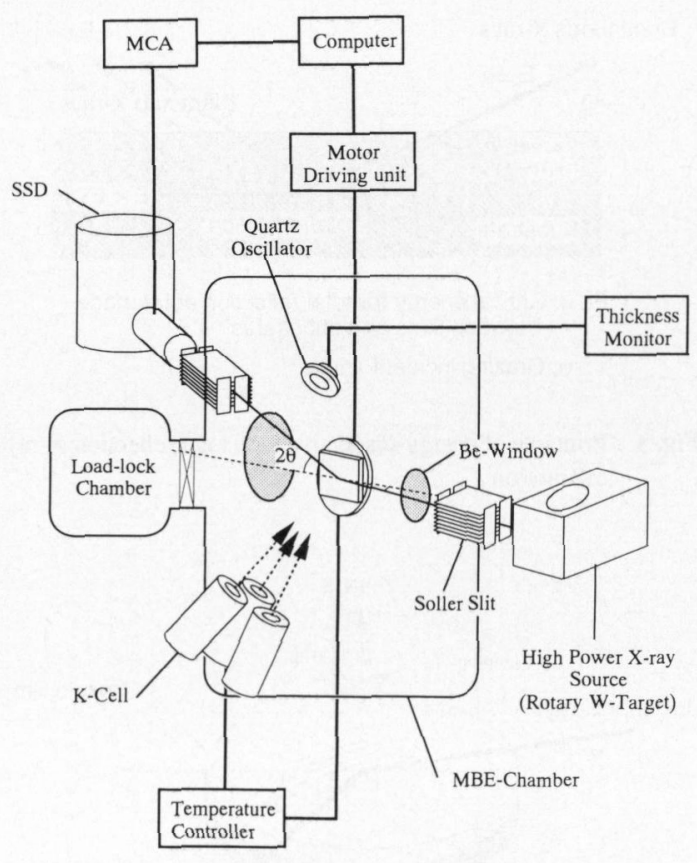

Fig. 3 A schematic illustration of TRXD-OMBD system.

測定を可能にしている。OMBD 超高真空装置の到達真空 度は $3 \times 10^{-8} \mathrm{~Pa}$ であり, クヌーセン・セル（Kセル）か ら分子線として有機分子を制御しながら結晶性の高い蒸 着膜を作製する。また，膜厚は基板の側に取り付けた水 晶振動子により計測して, 更に触針法による校正を行っ た。

また本手法では，全反射条件下での基板・薄膜からの 蛍光X線および回折 X線を検出することになるが，各々 の検出X線から様々な情報が得られる。まず, 薄膜から の蛍光 $\mathrm{X}$ 線より基板に付着した量が見積もられ，回折 $\mathrm{X}$ 線からはその凝集構造が解析される。一方, 基板からの 蛍光 X線より付着・凝集による基板表面の被覆状態を観 測することができ，基板が単結晶の場合にはその回折 X 線から基板表面の構造と薄膜の配向・構造との方位関係 の解析（エピタキシー評価）に用いられる。本稿では, まず薄膜および基板の回折 X線から初期過程でのエピタ キシーのその場観測について述べる。また，基板の蛍光 $\mathrm{X}$ 線から被覆過程をその場観測して薄膜形態評価の可能 性について検討した。

\section{3. $\mathrm{Ag}$ 基板面での $\mathrm{C60}$ 超薄膜のその場観測}

本実験では，試料としてフラーレン（C60，TermUSA 社製，99.98\%）を用いた。また，空気中で雲母（mica） を䢃開して，その（001）面に銀（Ag，99.99\%）を基板 温度 $300{ }^{\circ} \mathrm{C}$, 膜厚 $50 \mathrm{~nm}$ で真空蒸着したものを基板とし

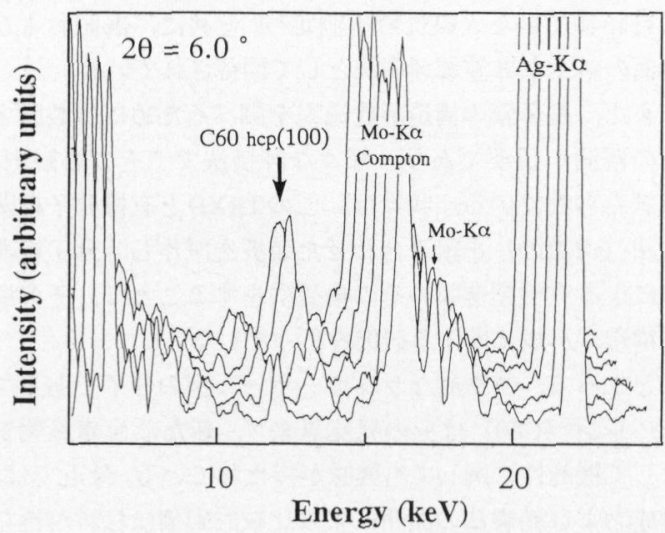

Fig. 4 In-plane TRXD profiles of $\mathrm{C} 60$ ultrathin film on $\mathrm{Ag}$ (111) during the deposition. The profiles were measured at the thickness of 0 (front), 4.3, 7.4, 10.5, 14.0 and 15.5 (back) nm. The growth of diffraction peak of hcp (100) was observed with increasing the thickness.

た。作製した基板は，X線による測定の結果，mica （001）面上に Ag（111）面が形成されていた。更に, TRXDによる面内構造解析の結果, mica (100) 面に対し てAg (220) 面が高度に配向しており，Agがエピタキシ ヤル成長していることを確認した。

この $\mathrm{Ag}$ エピタキシャル基板上に，Kセル温度 $420^{\circ} \mathrm{C}$, 蒸着速度 $0.002 \mathrm{~nm} / \mathrm{sec}$, および基板温度 $200^{\circ} \mathrm{C}$ の条件で, 膜厚 $15 \mathrm{~nm}$ までの C60超薄膜の形成過程をTRXDにより その場観測した。観測中, X線の入射角は臨界角近傍の $0.10^{\circ}$ に固定した。

また蛍光 X線の測定に関しては, Si（100）ウェハー 上に基板温度室温, 膜厚 $8 \mathrm{~nm}$ 程度で $\mathrm{Ag}$ を蒸着した平滑 性の高い基板を用いて, 660 薄膜形成に伴う $\mathrm{Ag}$ の蛍光 $\mathrm{X}$ 線強度の減衰を，全反射条件下でその場観測することで 薄膜形態の評価を試みた。

\subsection{C60超薄膜の面内凝集構造のその場観測}

Fig. 4 に膜厚 0 から $15.5 \mathrm{~nm}$ までの形成過程における C60超薄膜の各 in-plane TRXDプロファイルを示す。プロ ファイル中の数本のピークは, スリットおよび基板から の蛍光 X線である $\mathrm{Ag}-\mathrm{K} \alpha, \mathrm{Ag}-\mathrm{K} \beta, \mathrm{Mo}-\mathrm{K} \alpha, \mathrm{Mo}-\mathrm{K} \beta$, それ に付随した非弾性散乱および escape peakによるものであ る。膜厚の増加に伴い面間隔 $d=0.866 \mathrm{~nm}$ の回折ピーク が成長しており，これはC60の hcp構造の（100）面に対 応するものであった。Fig. 5 には膜厚に伴う hcp (100) の積分強度と面間隔の変化をプロットしたものを示す が，その面間隔はほぼ一定で強度は直線的に増加してい た。従って, 極初期から Ag (111) 結晶面で hcp構造が 安定に形成されていることが明らかになった。

次に, 膜厚 $15 \mathrm{~nm}$ まで成長させたC60超薄膜について, 

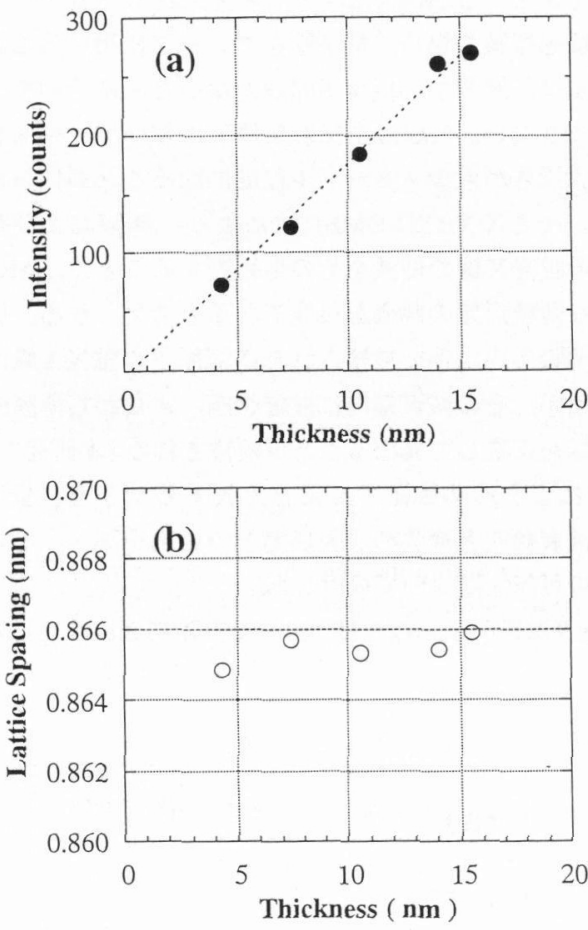

Fig. 5 The dependence of the thickness on (a) the intensity and (b) the lattice spacing of diffraction peak of hcp (100). It was observed that the intensity linearly increased and the lattice spacing was constant at initial process.

面内凝集構造とその基板面との方位関係を調べた。Fig. 6 （a）および（b）に示すように hcp（100）の他に hcp （110）に対応する回折ピークが観測され，双方のピーク 共に面内方位角 $\phi$ の変化に伴い回折強度が急激に減少し た。それぞれのピークに関して積分強度の $\phi$ 依存性をプ ロットした結果をFig. 7亿示す。hcp（100）の回折ピー ク強度が最大值をとる方位角を $\phi=0^{\circ}$ として, $\pm 1^{\circ}$ 以内 で hcp（100）が急激に消滅した。基板の Ag（220）の回 折強度最大の方位角 $\left(\phi=0^{\circ}\right)$ が hcp (100) の回折強度 最大の方位角と一致していたことから, 基板に対して薄 膜がエピタキシャル成長していることが確認された。ま た, Fig. 7 のプロットは結晶の配向分布を表しており, $\mathrm{C} 60$ 結晶の $\mathrm{Ag}$ 基板への極めて高い配向性を示している。 更に, hcp（110）については $\phi= \pm 30^{\circ}$ で最大値となる ことから，Fig. 8に示すようなエピタキシャル方位関係 でC60超薄膜が成長していると考えられる。

Altman らのSTMによるC60初期層の観測によると， $\mathrm{C} 60$ はfcc構造をとって Ag（111）面にエピタキシャル成 長しており，その六方格子が $\mathrm{Ag}$ （111）に対して熱力学 的に最を安定な $(2 \sqrt{3} \times 2 \sqrt{3}) \mathrm{R} 30^{\circ}$ 構造を形成している
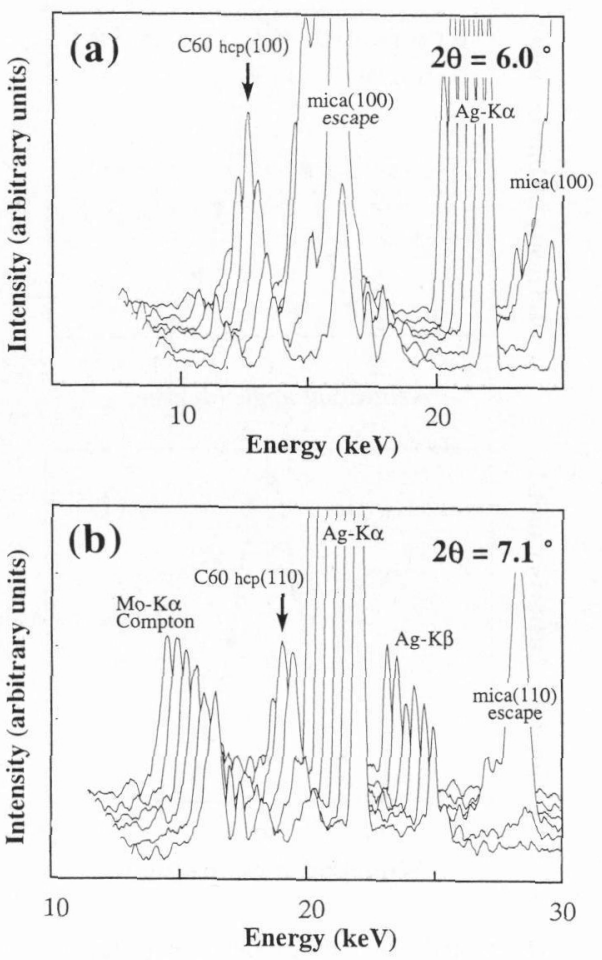

Fig. 6 The dependence of the azimuthal angle $(\phi)$ on the TRXD profiles of the $\mathrm{C} 60$ thin films at the diffraction angle of $6.0^{\circ}$. The diffraction peaks of (a) hcp (100) and (b) hcp (110) almost disappear when the azimuthal angle is $\pm 1^{\circ}$.

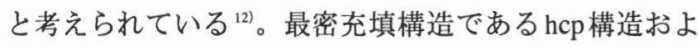
び fcc構造は共に六方対称を有しており，第 1 層目では 双方とも基板面に対して同じ $(2 \sqrt{3} \times 2 \sqrt{3})$ R $30^{\circ}$ 構造 が生じ得る。一般に単結晶では fcc 構造が最も安定とさ れているが, 僅かな成長条件（不純物, 成長温度) の相 違により hcp 構造も安定に生じ得ることが知られている。 特に薄膜の場合, 双方の構造が混在して形成されること があり, 現時点でその成長条件は明らかにされていると は言い難い"1)。いずれにしても初期層では, $(2 \sqrt{3} \times 2 \sqrt{3})$ $\mathrm{R} 30^{\circ}$ 構造により $\mathrm{C} 60$ の $\mathrm{Ag}$ （111）にエピタキシャル成長 して抢り,これが高配向形成の起源であると考えられ る。

\section{$3.2 \mathrm{C60}$ 超薄膜の薄膜形態のその場観測}

半導体薄膜の研究において, その島状および層状等の 薄膜成長形態の非破壊その場観測が非常に重要である。 一般に, RHEEDによる回折強度振動の観測やオージェ 電子分光法 (AES) による吸着原子および基板原子の信号 強度增減の観測によりその成長形態を評価している ${ }^{18)}$ 。 また, 電子線を照射して薄膜からの 2 次的な蛍光 $X$ 線の 

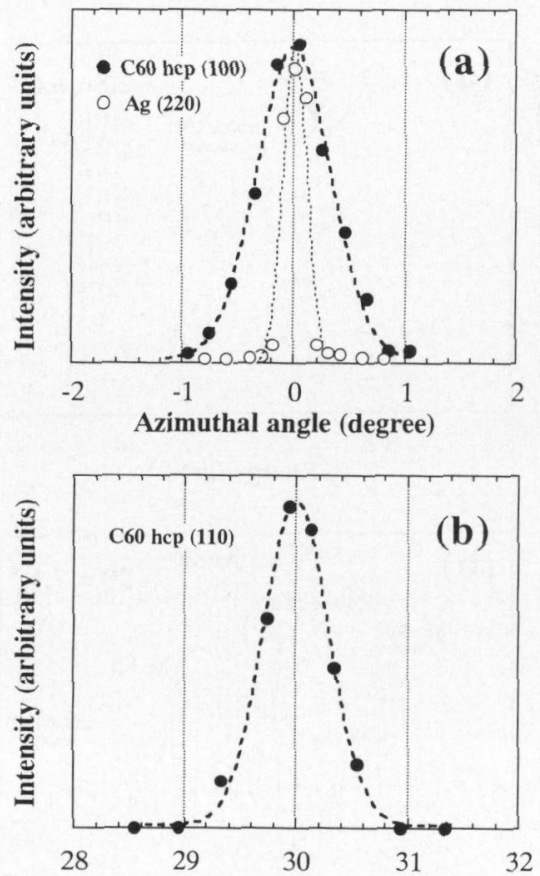

Azimuthal angle (degree)

Fig. 7 The dependence of the azimuthal angle $(\phi)$ on the intensity of (a) hcp (100) and (b) hcp (110). It is defined that the azimuthal angle of $0^{\circ}$ is equal to the $\mathrm{Ag}[110]$. The intensity of hcp (100) is maximum when $\phi=0^{\circ}$, and the intensity of hcp (110) is maximum when $\phi=30^{\circ}$.

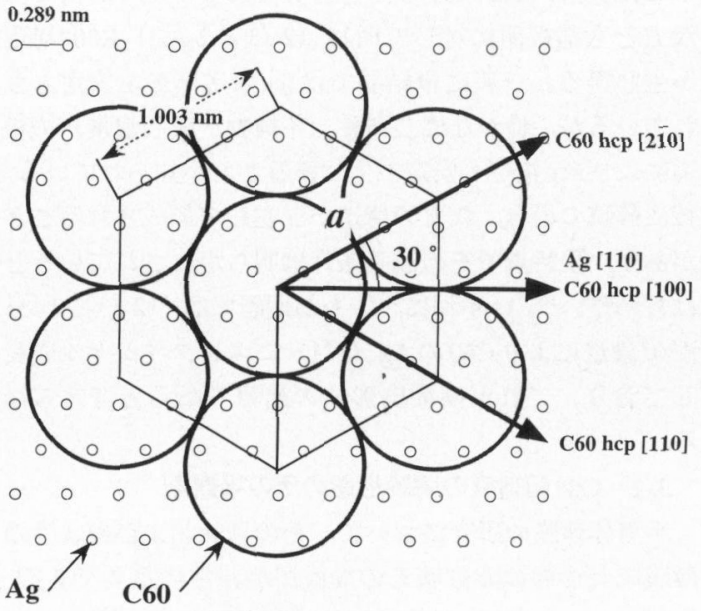

Fig. 8 A schematic illustration of the $\mathrm{Ag}$ (111) surface and the $(2 \sqrt{3} \times 2 \sqrt{3}) \mathrm{R} 30^{\circ}$ structure of $\mathrm{C} 60$ in the epitaxially grown thin films. The lattice spacing of $(2 \overline{1} 0)$ is equivalent to that of (110).
増減を観測するTRAX法なども考案されている ${ }^{19) 。 ~}$

有機超薄膜の場合, 電子線をプローブに用いるこれら の方法は, 観測中の損傷が問題となるためにそのまま適 用はできない。X線は全反射条件下において，表面から の侵入深さが数ナノメートル程度になることが知られて いる。そこでTRXD-OMBD法により, 薄膜および基板 原子の蛍光 $X$ 線の増減をその場観測することで, AESと 同様な薄膜形態の評価が可能であると考えられる。例え ば, 薄膜形成に伴い被覆された基板原子の蛍光 $\mathrm{X}$ 線は減 衰するが,，その減衰傾向は被覆状態，すなわち薄膜の成 長形態を反映して異なることが期待される。本研究では, AFMによる形態観測の結果と比較することで, 蛍光 X 線の減衰傾向と薄膜の成長形態との相関を調べ, その場 観測の可能性について検討した。

Fig. 9 は異なる基板温度（ $T_{\mathrm{s}}$ ) でその場観測したC60超
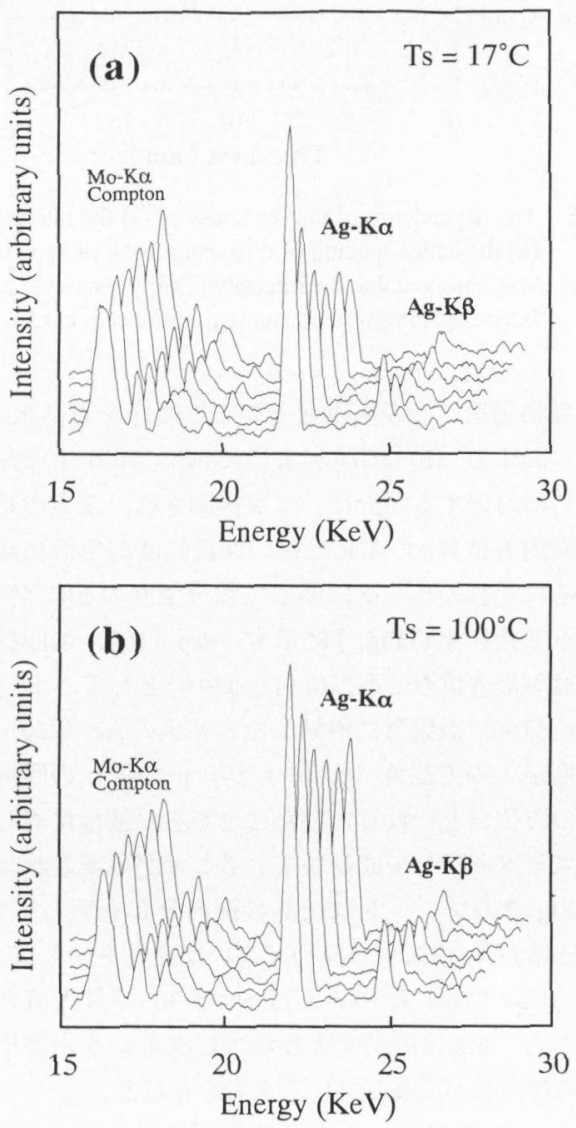

Fig. 9 Total reflection fluorescence X-ray profiles of C60 ultrathin films during the deposition at the substrate temperature of (a) 17 and (b) $100{ }^{\circ} \mathrm{C}$. The profiles were measured at each thickness from 0 (front) to 15.5 (back) nm. 


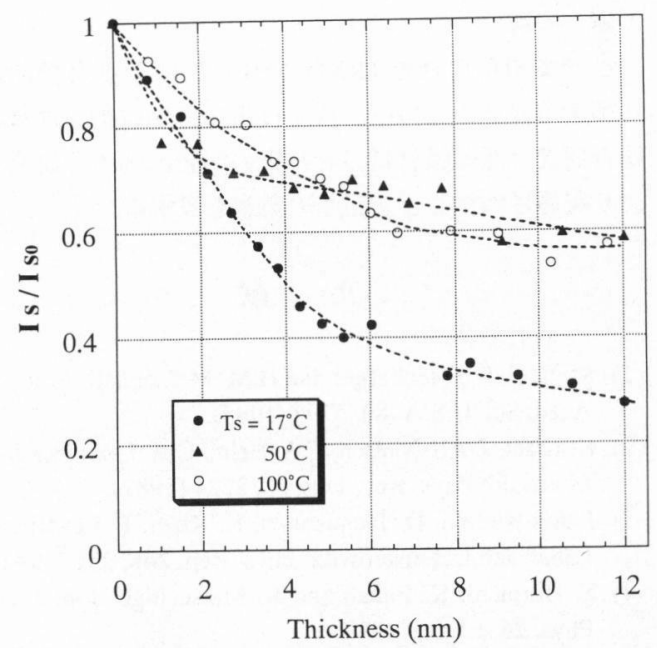

Fig. 10 The decay curves of normalized integral intensities of $\mathrm{Ag}-\mathrm{K} \alpha$ fluorescence $\mathrm{X}$-rays at the substrate temperature of 17,50 , and $100{ }^{\circ} \mathrm{C}$.

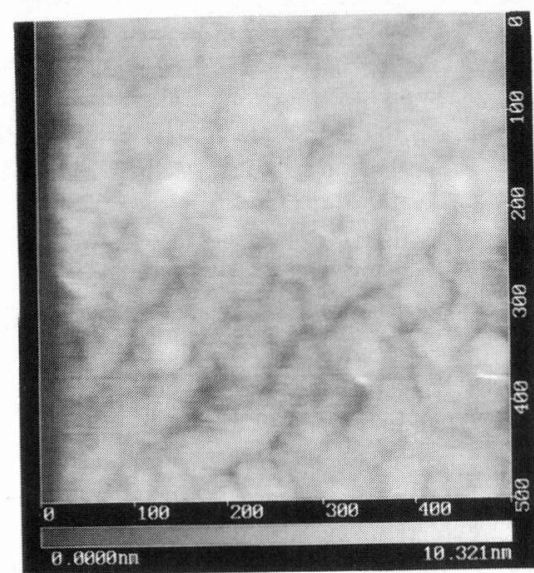

$\mathrm{Ts}=17^{\circ} \mathrm{C}$

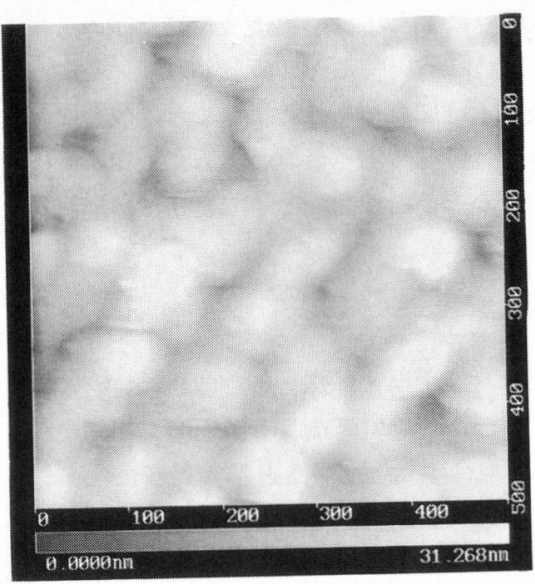

$\mathrm{Ts}=50^{\circ} \mathrm{C}$

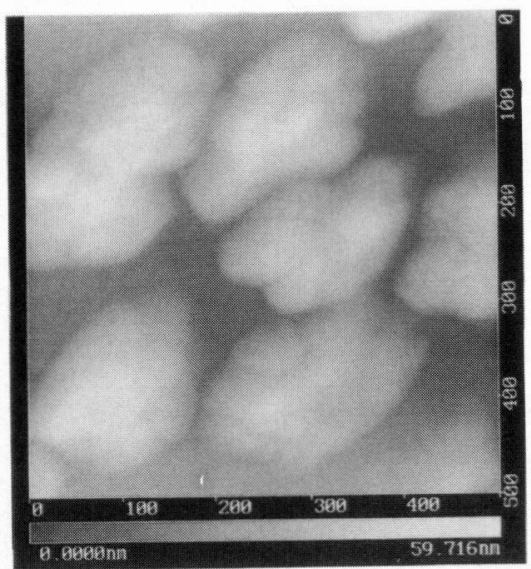

$\mathrm{Ts}=100^{\circ} \mathrm{C}$

Fig. 11 AFM images $(500 \times 500 \mathrm{~nm})$ of $\mathrm{C} 60$ ultrathin films at the thickness of $10 \mathrm{~nm}$. 
薄膜の全反射蛍光 $X$ 線プロファイルの変化を示す。共に $\mathrm{C} 60$ の堆積に伴い基板からの Ag-K $\alpha$ および $\mathrm{Ag}-\mathrm{K} \beta$ が減衰 している。これは明らかに 600 の被覆に伴う隇衰である ことが考えられるが, 基板温度により減衰傾向が異なっ ていた。

そこで, 各膜厚での Ag-K $\alpha$ 積分強度（I）を膜厚 $0 \mathrm{~nm}$ の時の積分強度 $\left(I_{\mathrm{s} 0}\right)$ で規格化した量 $\left(I / I_{\mathrm{s} 0}\right)$ を, 膜厚 に対してプロットしたものを Fig. 10に示す。膜厚の増加 に伴い, $T_{\mathrm{s}}=17^{\circ} \mathrm{C}$ では急激に減衰したのに比べて, $T_{\mathrm{s}}=$

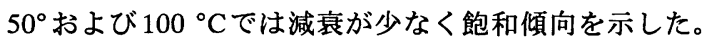
作製後, 各々の 60 薄膜を AFMにより観察した結果, Fig. 11 に示すように $T_{\mathrm{s}}=17^{\circ} \mathrm{C}$ では比較的平滑な層状の 薄膜が形成されているのに対して， $T_{\mathrm{s}}=50^{\circ}$ および 100 ${ }^{\circ} \mathrm{C}$ では島状に成長して基板面が露出していた。従って, 減衰曲線は薄膜の被覆度と形態を表していると考えられ るが，この減衰曲線に関しては，更に定量的な議論をす る必要があると思われる。特にAESで行われているよう に, 単層で成長する薄膜に対しては 1 層ごとの成長に関 する定量的な評価が可能であると思われる。今後, 有機 超薄膜の成長形態のその場観測法として有効に用いられ ることが期待される。

\section{4.おわりに}

TRXD-OMBD 法により $\mathrm{Ag}$ 基板上での C60蒸着膜につ いてその場観察を行い, その構造および配向を初期層か ら評価した。C60超薄膜はhcp構造をして高度に配向し ており，基板の Ag（111）面に対して（2 $\sqrt{3} \times 2 \sqrt{3} ）$ $\mathrm{R} 30^{\circ}$ 構造でエピタキシャル成長していることが観測され た。また基板の蛍光 $\mathrm{X}$ 線の隇衰曲線から, $\mathrm{C} 60$ 超薄膜の 成長形態の評価が可能であることを示した。

このように，TRXD-OMBD法はエネルギー分散型測定 の利点と薄膜 - 表面の高感度測定法の利点を合わせ持つ ため, 有機超薄膜に限らず様々な薄膜・表面の動的解析 への適用が考えられ, 多目的な評価法として今後効力を 発揮することが期待される。

\section{謝 辞}

ここで引用された TRXD-OMBD法による有機超薄膜 に関する研究の一部は, 科学技術庁科学技術振興調整費 総合研究「超薄膜材料設計技術の開発に関する研究」に より実施されたことを記して謝意を表する。

\section{立献}

1) M. Seul, P. Eisenberger and H.M. McConnell: Proc. Natl. Acad. Sci. U.S.A. 80, 5795 (1983).

2) K. Kjaer, J. Als-Nielsen, C.A. Helm, C.A. Laxhuber and H. Möhwald: Phys. Rev. Lett. 58, 2224 (1987).

3) J. Als-Nielsen, D. Jacquemain, K. Kjaer, F. Leveiller, M. Lahav and L. Leiserowitz: Phys. Rep. 246, 251 (1994).

4) T. Horiuchi, K. Fukao and K. Matsushige: Jpn. J. Appl. Phys. 26, L1839 (1987).

5) K. Ishida, K. Hayashi, T. Horiuchi and K. Matsushige: J. Appl. Phys. 73, 7338 (1993).

6) N. Tanigaki, K. Yase, Y. Yoshida, Y. Kyotani and A. Kaito: Rept. Prog. Polym. Phys. Jpn. 38, 269 (1995).

7) K. Sakurai and A. Iida: Jpn. J. Appl. Phys. 31, L113 (1992).

8) Y. Yoshida, N. Tanigaki and K. Yase: Mol. Cryst. Liq. Cryst. 280, 271 (1996).

9) Y. Yoshida, N. Tanigaki and K. Yase: Thin Solid Films 281/282, 80 (1996).

10) H.W. Kroto, J.R. Heath, S.C. O'Brien, R.F. Curl and R.E. Smally: Nature 318, 162 (1985).

11) K. Tanigaki, S. Kuroshima and T.W. Ebbesen: Thin Solid Films 257, 154 (1995).

12) E.I. Altman and R. Colton: Surf. Sci. 295, 13 (1993).

13) T. David, J. K. Gimzewski, D. Purdie, B. Reihl and R.R. Schlittler: Phy. Rev. B 50, 5810 (1994).

14) A. Fartash: Mat. Res. Soc. Symp. Proc. 359, 393 (1995).

15) T. Hashizume, Q. Xue and T. Sakurai: 第 10 回フラーレン 総合シンポジウム予稿集, p. 49.

16) L.G. Parratt: Phys. Rev. 95, 359 (1954).

17) H. Dosch: Phys. Rev. B 35, 2137 (1987).

18) L.C. Feldman and J. W. Mayer: "Fundamentals of Surface and Thin Film Analysis” (Elsevier Sci. Pub., 1986); “表面 と薄膜分析技術の基礎”, 栗山, 山本訳 (海文堂, 1989) p.141.

19) S. Hasegawa, H. Daimon and S. Ino: Surf. Sci. 186, 138 (1987). 